\title{
PENYELESAIAN PERSOALAN TANAH PERKEBUNAN DALAM PERSPEKTIF SOCIO LEGAL (STUDI PADA BEBERAPA PERKEBUNAN DI JAWA TIMUR) ${ }^{1}$
}

\author{
Imam Koeswahyono ${ }^{2}$
}

\section{Abstrak}

The author publishes his research report concerning plantation land problems. The research is aimed to result clarifications how far the resolution to accomplishing plantation land disputes. Study has been done to find correlation between one of the land reform programs by land redistribution model and plantation land disputes. To giving accurate data and touching the focus study the author use socio-legal methods and by field observation in land dispute areas where located. The analysis is also made on corporate social responsibility angle to detect it effectiveness on land dispute reduction in conflict area both in effective plantation and ineffective area. The research is also purposed to give alternative concept for better model on plantation lands management in the future.

Kata kunci: hukum pertanahan, tanah perkebunan, socio legal, landreform, Jawa Timur

\section{Pendahuluan}

Pada sepuluh tahun terakhir ini usaha perkebunan swasta di Jawa Timur ternyata tidak berjalan dengan baik karena banyak timbul masalah,

${ }^{1}$ Makalah yang disampaikan pada "Seminar Nasional Penelitian Dalam Perspektif Socio Legal" di selenggarakan oleh Bagian Hukum dan Masyarakat Fakultas Hukum Universitas Diponegoro, Semarang pada Senin, 22 Desember 2008 di Gedung Pascasarjana Universitas Diponegoro. Makalah ini disarikan dan modifikasi dari Laporan Hasil Penelitian Hibah Bersaing XV-1 Tahun Anggaran 2007/ 2008 yang disusun oleh tim dengan susunan Ketua Dr.Suhariningsih SH.MS, Anggota: Imam Koeswahyono SH MH, Istislam, SH.MH serta Dianawati STP.MP penulis menyampaikan terima kasih atas pemberian izin mengadaptasi isi tulisan dan kerjasamanya. Pemodifikasian dan penyesuaian isi makalah ini merupakan pendapat pribadi dan bukan merepresentasikan pendapat tim maupun lembaga Fakultas Hukum Unibraw.

${ }^{2}$ Penulis adalah Dosen Tetap Fakultas Hukum Universitas Brawijaya Malang sejak 1986, sejak 2007 menempuh Program S-3 llmu Hukum Konsentrasi Agraria Program Pascasarjana Ilmu Hukum Univ. Brawijaya Malang. 
seperti produksi macet, tanaman tidak sesuai, upah tenaga kerja amat rendah, bahkan ada yang belum terbayar. Masalah lainnya seperti lahan diduduki rakyat, lahan disewakan oleh pemegang HGU, lahan HGU menjadi obyek sengketa yang massif, berlarut-larut dan melibatkan banyak pihak dan kepedulian serta pengawasan pernerintah kabupaten yang lemah. Sementara itu, pada sisi lain, pemegang HGU (perkebunan) mengabaikan tanggung jawab sosialnya terhadap komimitas atau masyarakat di sekitar perkebunan.

Beberapa contoh kasus tanah HGU terjadi di Perkebunan Gangsar (Blitar) dengan SK HGU No. 19/HGU/DA/1973 dan SK No. 20/HGU/DA/1973 tanggal 21 April 1973 dari Menteri Dalam Negeri, dan HGU berakhir tanggal 31 Desember 1998. Masyarakat sekitar menuntut areal HGU seluas $\pm 212 \mathrm{HA}$, agar diredistribusikan; ternyata lahan HGU dijadikan agunan kredit bank, pekerja perkebunan tersebut upahnya belum terbayar \pm lima tahun. Kemudian kasus perkebunan kakao (coklat) di Kabupaten Malang, kasus Perkebunan Sumbersekar di Kabupaten Kediri. Kasus-kasus pengelolaan $\mathrm{HGU}$ perkebunan tersebut memiliki persamaan dan perbedaan karakteristik dan sampai kini masih belum ada penyelesaiannya yang selaras dengan kepastian hokum dan keadilan.

Lahan HGU pada dasarnya bukan termasuk obyek landreform, yaitu program strategi pembaharuan struktur penguasaan tanah untuk mencapai keadilan dalam perolehan dan pemanfaatan tanah pertanian. Namun banyak tanah-tanah pertanian milik rakyat pada waktu itu dirampas untuk kepetingan usaha perkebunan besar (zaman Belanda), dan itu diserahkan kepada pengusaha-pengusaha swasta. Rakyat kehilangan aset/faktor produksi pertanian, rakyat menjadi pekerja/buruh untuk bekerja di perkebunan besar milik pengusaha swasta. Itu sebabnya dengan landreform pernerintah di zaman Orde Lama hendak mengembalikan tanah-tanah rakyat/petani melalui Pasal 7, 10, 17 UU No.5 Tahun 1960, UU No. 56 Prp Tahun 1960 dan peraturan pelaksananya PP No. 224 Tahun 1961.

Perkembangannya sejak pemerintahan Orde Baru, pembangunan yang dirancang dalam Repelita mengutamakan pembangunan ekonomi dan tanah berubah fungsi menjadi komoditi dan ekonomi kapitalistik. Terdapat kecenderungan pernerintah berpijak pada kepentingan kelompok investor. Melalui kemudahan-kemudahan prosedur, para investor dengan leluasa dan gampang mendapatkan hak atas tanah untuk diusahakan. Namun, ketika krisis ekonomi melanda dunia termasuk Indonesia, para investor banyak yang mengalami kerugian, dan akibatnya tidak mampu melanjutkan usaha bahkan ada yang melepaskan pengelolaan tanahnya. 


\section{Metode Penelitian}

Penelitian yang dirancang merupakan penelitian socio-legal,penelitian ini memilih pendekatan socio-legal merujuk pandangan Banakar dan Travers "inter disciplinarity provides a space encounter at the cross section of disciplines which offers temporary relief from methodological and theoritical restrictions of established disciplines. Aktivitas penelusuran data lapang yang berkaitan dengan diterapkannya kebijakan dan norma yang mengatur pengelolaan HGU (perkebunan) dalam realita.

Tentu pertanyaan yang mengemuka adalah mengapa memilih cara pendekatan ini?jawabannya mengacu pendapat BZ.Tamanaha (2006) yang menyitir pandangan Vago (1981) law is a mirror of society, which functions to maintain social order. Every legal system stand in a closerelationship to the ideas, aims and purposes of society. Law reflects the intellectual, social, economic and political climate of it's time. Penelitian bertujuan mengulas ulang, bagaimana kaidah-kaidah hukum bekerja (in action) di masyarakat dipengaruhi dan mempengaruhi variabel-variabel non-hukum seperti: ekonomi, politik, budaya. ${ }^{3}$ Dengan demikian, penelitian akan mengupas, teori-teori dan azas-azas kebijakan publik oleh pemerintah, ekonomi, budaya yang tertemukan pada wilayah yang diteliti. ,

Hasil kajian tersebut dijadikan sebagai salah satu dasar pertimbangan dirumuskan suatu model manajemen HGU (perkebunan) yang dicitakan. Pemaknaan fenomena hukum secara sosiologik seperti persoalan tanah perkebunan dimana terjadi perubahan pemaknaan tanah sebagai aset menjadi tanah sebagai komoditi, komunal ke privatisasi terjadi perubahan relasi antara manusia dengan obyek (tanah) seperti kajian Franz von Benda Beckmann dkk (2006) tidak dapat dipisahkan dalam kerangka hubungan sosial yang luas" sejalan pandangan Cotterrel tidak saja beirmanfaat melainkan suatu keniscayaan, agar mendapatkan pemahaman hukum yang benar.

Penelitian ini merupakan suatu proses penelitian yang saling berkaitan antara tahap pertama dan tahap kedua, guna mencapai satu tujuan penelitian. Penelitian ini dilakukan di tiga lokasi penelitian yaitu:

1. Desa Sumbersekar, kecamatan Ngadilangkung, Kabupaten Blitar;

${ }^{3}$ Kajian demikian ini sangat bermanfaat bagi pembetajaran hukum agraria dan pengantar antropologi hukum di Fakultas Hukum Universitas Brawijaya seperti dilakukan oleh penulis, periksa Imam Koeswahyono, Konflik Agraria di Jawa Timur dan Kemanfaatannya Untuk Pembelajaran Socio-Legal di Fakultas Hukum, dalam Jurnal Masalah-masalah Hukum Volume 36 No.3 Juli-September, Fakultas Hukum Universitas Diponegoro, Semarang, 2007, hal.231 - 240. 
2. Desa Sempu, Kecamatan Ngadilangkung, Kabupaten Kediri;

3. Desa Wonokitri, Konten, Kabupaten Malang (pengganti Perkebunan Kalibakar, Desa Tirtoyudo).

Ketiga lokasi penelitian tersebut dipilih dengan alasan bahwa perkebunan yang ada tersebut (Blitar dan Kediri) merupakan perkebunan:

1. pernah mengalami surplus produksi dengan komoditi kualitas ekspor (kopi dan cengkeh);

2. mengalami kehancuran usaha di masa tumbangnya Orde Baru, karena terjadi konflik pertanahan antara penduduk/masyarakat sekitaf perkebunan dengan pengusaha perkebunan (terjadi reclaiming, perusakan tankman dan peralatan pabrik, intimidasi terhadap staf perkebunan);

3. saat ini sedang dalam kondisi merintis kembali usaha perkebunan.

Sedangkan untuk lokasi yang ketiga dipilih dengan alasan sebagai contoh pengelolaan HGU (perkebunan) yang telah berhasil baik dari segi komoditi maupun tanggung jawab sosial subyek HGU. Perlu diketahui bahwa PT Perkebunan Nusantara XII di Wonokitri adalah BUMN yang berhasil mempertahankan pelaksanaan pengelolaan perkebunan yang telah memberikan kesejahteraan pada para pekerjanya maupun masyarakat sekitar (sampai radius $30 \mathrm{~km}$ ).

Responden penelitian ini ditentukan secara purposive sampling menjadi empat kelompok, meliputi:

1. Kepala Kantor Pertanahan dan staf di masing-masing lokasi penelitian;

2. Pemegang HGU (Perkebunan) dan staf di masing-masing lokasi penelitian;

3. Kepala Dinas perkebunan dan staf di masing-masing lokasi penelitian;

4. Kepala desa dan tokoh masyarakat di masing-masing lokasi penelitian, serta masyarakat sekitar perkebunan baik yang menjadi pekerja di perkebunan maupun yang tidak.

Untuk memenuhi persyaratan statistik non parametrik, maka dibutuhkan tujuh orang bagi tiap kelompok responden, sehingga total dibutuhkan 28 orang bagi keempat kelompok masyarakat sebagai responden.

Kemudian analisis data yang digunakan adalah deskriptif-kualitatif empiris, analisis isi (content analysis) menggunakan statsitik non parametrik dan uji komparatif. 


\section{Hasil Penelitian dan Pembahasan}

\section{A. Gambaran Umum Lokasi Penelitian}

\section{Perkebunan Gangsar (Kabupaten Blitar)}

Perkebunan Gangsar terletak di Dusun Gangsar, Desa Sumberasri, Kecamatan Ngrekoso, Kabupaten Blitar. Pemegang HGU perkebunan Gangsar adalah PT. Perkebunan dan Dagang Gangsar dengan direkturnya yaitu RW dengan SK HGU No. 19/HGU/DA/1973 dan SK No. 20/HGU/DA/1973 tanggal 21 April 1973 dari Menteri Dalam Negeri, yang berakhir tanggal 31 Desember 1998 dan sekarang ini HGU perkebunan Gangsar telah diperpanjang sampai dengan tahun 2015. Luas perkebunan Gangsar saat ini adalah $613 \mathrm{Ha}$, yang semula seluas 825,4363 $\mathrm{Ha}$ dan telah diredistribusikan kepada masyarakat sekitar seluas 212 Ha. Komoditas asli perkebunan ini adalah kopi dan cengkeh.

\section{Perkebunan Sumbersekar (Kabupaten Kediri)}

Perkebunan Sumbersekar terletak di Kecamatan Ngadilangkung, Kabupaten Kediri. Lokasi perkebunan ini berada dan dikelilingi tiga desa yaitu Desa Sempulur, Desa Bibrikan dan Desa Sugihseger. Adapun keadaan geografisnya mayoritas berlereng $15 \%-25 \%$ dengan ketinggian antara $485 \mathrm{~s} / \mathrm{d} 680 \mathrm{~m}$ dpi dan merupakan daerah penyangga antara daerah lindung dan daerah budidaya. Pemegang HGU perkebunan Sumbersekar adalah PT.Private Development Finance Company of Indonesia, dengan direkturnya yaitu P. HGU Perkebunan Sumbersekar ini telah berakhir pada tahun 1999 dan perpanjangannya masih dalam proses. Luas perkebunan Sumbersekar semula 654,92 Ha dan telah diredistribusikan kepada masyarakat di tiga desa sekitar perkebunan seluas $250 \mathrm{Ha}$, sehingga sisanya seluas 384,274 Ha. Adapun sisa tanah yang 20,544 Ha dikecualikan karenaberupajalan, sungai dan tebing. Komoditas asli tanaman perkebunan Sumbersekar adalah kopi, karet dan cengkeh.

\section{Perkebunan Wonokitri (Kabupaten Malang)}

Perkebunan Wonokitri terletak di Kecamatan Konten, Kabupaten Malang, yang terletak pada ketinggian antara 9501250 meter dari permukaan laut. Perkebunan Wonokitri 
merupakan salah satu perkebunan yang dikelola oleh PT. Perkebunan Nusantara XII (Persero). Komoditas utama perkebunan Wonokitri adalah teh.

\section{Kontroversi Subyek, Obyek HGU, Reclaiming, CSR}

Dalam sekian banyak literatur disebutkan bahwa Hak Guna Usaha (selanjutnya disingkat HGU) sebagaimana diatur pada Pasal 28-34 Undang-undang No.5 Tahun 1960 diberikan oleh pemerintah atas nama negara untuk tiga macam kegiatan usaha yakni: pertanian, peternakan atau perikanan pada perusahaan dalam kerangka investasi di sektor agro industri.

Secara prosedural menurut UUPA yo PP No.4G tahun 1996, calon subyek HGU mengajukan permohonan kepada Badan Pertanahan Nasional (Kantor Pertanahan) untuk luas tanah minimal lima hektar sampai maksimal duapuluh lima hektar, jika lebih luas dari yang ditentukan dapat diperkenankan asal memenuhi persyaratan memiliki modal usaha yang mencukupi dan dikuasainya teknologi usaha di sektor itu secara baik.

Dalam konteks pembinaan yang menjadi kewajiban pemerintah secara teknis dilakukan oleh Dinas Perkebunan provinsi misalnya tentang jenis tanaman, pola tanam, usaha tanaman dan sebagainya. Sedangkan pembinaan dari aspek aspek yuridik atas hubungan subyek, dengan tanahnya yang berarti berkaitan dengan hak dan kewajiban adalah menjadi tugas Badan Pertanahan Nasional (BPN). Pemberian HGU sebagaimana terruang pada Surat Keputusan Pemberian Hak (selanjutnya disingkat SKPH) memberikan hak kepada subyek HGU setelah yang bersangkutan memenuhi persyaratan-persyaratan sebagimana ditentukan dalam Pasal 28-34 Undang-undang No.5 Tahun 1960 yuncto Peraturan Pemerintah No.40 Tahun 1996 tentang HGU, HGB dan Hak Pakai.

Disamping itu, peraturan perundang-undangan meletakkan kewajiban kepada penerima hak yang harus dipenuhi sebagai subyek HGU misalnya: jenis tanaman, luas areal dan sebagainya. Tidak dipenuhinya kewajiban sebagaimana ditentukan pada SKPH, maka memungkinkan pencabutan SKPH oleh negara (dalam hal ini Badan Pertanahan Nasional) dengan kewajiban negara untuk memberikan ganti rugi sebatas pada benda-benda yang terletak di atas tanah seperti: tegakan-tegakan pohon, bangunan-bangunan untuk aktivitas perusahaan dan sebagainya. 
Berdasarkan hasil FGD, nampaknya fungsi/peran Badan Pertanahan Nasional ini yang tidak dijalankan sebagaimana mestinya oleh Badan Pertanahan Nasional, sehingga dengan alasan untuk melakukan konservasi lahan dan melindungi komoditi dari penjarahan, maka banyak perusahaan perkebunan melakukan strategi untuk melakukan penggantian jenis tanaman misalnya cacao atau kopi menjadi karet atau tebu tanpa mendapatkan sanksi dari Badan Pertanahan Nasional. Berkaitan dengan hal demikian, maka menurut Peraturan Presiden No. 10 Tahun 2007 tentang Badan Pertanahan Nasional memiliki tugas pokok dan fungsi (tupoksi) untuk melaksanakan tindakan pengawasan dan penertiban atas semua produk hukum yang telah dikeluarkan, termasuk di dalamnya HGU. Deputi yang membawahi tugas hak atas tanah serta inspektur jenderal pengawasan (IrJen) seharusnya melakukan tindakan dalam degradasi/ tingkatan pelanggaran yang telah dilakukan institusi tersebut. Sementara itu, pembinaan secara tehnis dilakukan oleh Dinas Perkebunan provinsi misalnya mengenai pola tanam, jenis tanaman, panen, pasca panen dan sebagainya. Peran ini berdasarkan hasil FGD sudah dilaksanakan secara baik oleh institusi di bawah Departemen Pertanian ini, barangkali yang penting dalam era otonomi daerah berkait diundangkannya Undang-undang No.32 Tahun 2004 tentang Pemerintahan Daerah peran tersebut dapat dioptimalkan.

Bagi perkebunan peristiwa yang menyusul setelah tumbangnya Orde Baru tahun 1997/1998 membawa implikasi yang sangat berat baik dari sisi ekonomi, sosial maupun hukum bersangkut dengan areal perkebunan karena aksi-aksi reclaiming yang dilakukan secara sistematik dan massif. Menurut base data Konsorsium Pembaruan Agraria Tahun 2001 untuk Jawa Timur kasus tanah yang terjadi dapat diperiksa pada paparan tabel di bawah ini:

Tabel 1. Sengketa Pertanahan 1979-2001 di Jawa Timur menurut KPA (Bandung)

\begin{tabular}{|c|c|c|c|c|c|c|c|c|c|}
\hline No. & $\begin{array}{c}\text { Provi } \\
\text { nsi }\end{array}$ & $\begin{array}{c}\text { Juml } \\
\text { ah } \\
\text { Kasu } \\
\text { s }\end{array}$ & $\begin{array}{c}\text { Luas } \\
\text { Areal } \\
\text { konflik }\end{array}$ & $\begin{array}{c}\text { Jumlah } \\
\text { keluarga } \\
\text { korban }\end{array}$ & $\begin{array}{c}\text { Pihak } \\
\text { pemeri } \\
\text { ntah }\end{array}$ & $\begin{array}{c}\text { Perusa } \\
\text { haan } \\
\text { Negara }\end{array}$ & $\begin{array}{c}\text { Perusah } \\
\text { aan } \\
\text { Swasta }\end{array}$ & $\begin{array}{c}\text { Resolu } \\
\text { si } \\
\text { Tercata } \\
\text { t }\end{array}$ & $\begin{array}{c}\text { Metod } \\
\text { e } \\
\text { Resolu } \\
\text { si }\end{array}$ \\
\hline 1 & Jatim & 169 & 390.296 & 187.428 & 77 & 31 & 59 & $\begin{array}{c}93 \\
(55 \%)\end{array}$ & $\begin{array}{c}85 \\
(91,40) \\
\text { ADR }\end{array}$ \\
\hline
\end{tabular}

Sumber data: KPA Bandung dalam leaflet Toward Agrarian Reform in Indonesia, hlm 5-6 (diolah oleh Tim peneliti PHB XVI tahun 2008).

Data di muka, menunjukkan bahwa kasus yang berkaitan tanahtanah yang dikuasai oleh negara jumlahnya lebih banyak yakni 77 
termasuk di dalamnya perusahaan-perusahaan perkebunan negara disebut sebagai Perseroan Terbatas Perkebunan Negara (PTPN XII) dan perusahaan perkebunan swasta berjumlah 59. Wilayah PTPN XII meliputi sembilan unit kebun meliputi Kabupaten Ngawi, Kediri, Malang, Lumajang, Blitar, Jember, Pasuruan, Mojokerto, Banyuwangi. Dari data yang ada sebagian besar mengalami krisis degradasi baik sumber daya tanahnya, status hukum obyeknya maupun ekonomi finansialnya akibat peristiwa reclaiming. Berdasarkan hasil FGD, khususnya wilayah PTPN XII dari seluruh areal kebun yang dikelola hanya tinggal sekitar $60 \%$ yang sekarang dapat dipertahankan dari aksi-aksi reclaiming.

Reclaiming menurut Boedhi Wijardjo dan Herlambang Perdana (2001) adalah sebuah tindakan perlawanan yang dilakukan oleh rakyat tertindas untuk memperoleh kembali hak-haknya secara adil. Sebagai tindakan massa yang terencana/sistematik, keras reclaiming membawa dampak yang amat menggoncangkan sendi-sendi sosial, politik, ekonomi serta hukum masyarakat di Indonesia khususnya di Jawa Timur. Sebagai sebuah gerakan (movement), maka reclaiming memilikialasan atau dasar pembenar yakni:

1. Alasan moralitas yakni berkait dengan tindakan manusia yang dipandang baik-buruk, benar-salah, tepat-tidak tepat agar manusia mampu bergerak maju mengatasi persoalan realita. Tindakan reclaiming merujuk pada pemikiran dialektik sejak zaman kolonialsampai sekarang pemerintah atas nama negara telah melakukan tindakan tak bermoral dengan merampas secara semena-mena tanah milik rakyat;

2. Alasan ketidakadilan dan struktur yang menindas, hal demikian juga berlandaskan fakta kesejarahan sejak zaman kolonial terjadi ketimpangan secara tajam srtuktur penguasaan dan pemilikan atas sumber daya alam termasuk di dalamnya tanah. Disamping itu, terdapat pula ketimpangan dalam pemenuhan atas hak-hak ekonomi, sosial dan budaya yang sengaja diciptakan dan dilestarikan oleh rezim kekuasaan politik yang korup dan otoriter/ represif;

3. Alasan normatif (yuridik konstitusional) merujuk pada dasar konstitusional yakni Pasal 33 Ayat (3) Undang-undang Dasar 1945 dalam praktik politik ketatanegaraan, terbukti negara telah gagal dalam mengemban amanat rakyat dan kegagalan Majelis 
Permusyawaratan Rakyat (MPR) dalam mengemban kedaulatan rakyat menurut pasal 1 Ayat (2) Undang-undang Dasar $1945 .{ }^{4}$

4. Alasan hubungan sejarah dan nilai-nilai lokal yakni hubungan kesejarahan rakyat yang melakukan tindakan reclaiming dengan obyek yang direclaiming yakni hubungan fisik dan non-fisik. Masyarakat yang melakukan reclaiming telah menggarap tanah dalam rentang waktu yang lama bahkan sejak zaman kolonial;

5. Alasan kewajiban negara dalam pemenuhan kebutuhan dasar rakyat dengan mengacu pada ketentuan dalam preambule/pembukaan UUD 1945 yuncto Pasal 33 Ayat (3) UUD 1945 negara telah gagal memenuhi kewajiban, sehingga terjadi proses pemiskinan struktural secara besar-besaran baik politik, ekonomi, sosial-budaya.

Dalam khasanah teori politik dan sosial merujuk pada tesis Karl Marx dinyatakan bahwa praktik kehidupan masyarakat Indonesia terutama pada era Orde Baru telah menggunakan ideologi neokapitalisme yang sudah barang tentu terciptakan stratifikasi sosial kaum kaya-raya, kelas menengah serta kelas miskin. Kelompok pertama dan kedua menindas kelompok ketiga atau yang terakhir, sehingga pada titik kulminasi terjadilah perlawanan yang dikatakan terjadinya revolusi sosial yang memakan banyak korban. Proses tesis dan anti tesis yang menghasilkan sintesis ini pada gilirannya akan terhenti manakala sudah tidak ada lagi masyarakat tanpa kelas. Realitas menunjukkan kegagalan dari teorema para penganut faham sosialis ini bahwa masyarakat tanpa kelas pada akhirnya hanya ilusi belaka.

Fenomena chaos (keos) menyusul peristiwa Mei 1998 runtuhnya Orde Baru setelah tuntutan pelaksanaan landreform secara sepihak dengan redistribusi tanah-tanah yang telah direclaiming masyarakat, ternyata juga menghasilkan akibat ikutan yang justru bersifat kontra produktif. Tentu, pertanyaan yang mengemuka adalah mengapa terjadi peristiwa negatif ikutan pasca dipenuhinya tuntutan reclaiming yakni terjadinya tuan-tuan tanah (landlord) baru dan konflik horisontal.

${ }^{4}$ Bandingkan pandangan Prof Satjipto Rahardjo (2008) negara Indonesia seharusnya menjadi sebuah negara hukum yang Indonesia, negara yang membahagiakan rakyatmembumi ke dalam habitat, tradisi.nilai-nilai, kosmologi serta cita-cita moderen Indonesia. Dengan demikian membaca UUD 1945 bukan sekadar teks biasa melainkan pembacaan bermakna atau moral reading (membaca moral di belakang konstitusi tertulis itu. Demikian pula komitmen membangun manusia dilakukan dengan membangun dari dalam (development from within "(Satjipto Rahardjo, 2008: 100-107). 
Harapan akan kemakmuran sebagaimana dibayangkan oleh kelompok masyarakat yang melakukan reclaiming nampaknya tidak terwujud karena kondisi sosial-ekonominya stagnan bahkan ada yang menurun ${ }^{5}$. Beberapa bukti yang dapat dikemukakan untuk menjawab pertanyaan di muka adalah:

1. Kasus perkebunan Sekargadung dan Banyuurip di Kabupaten Blitar;

2. Kasus perkebunan Pancursari, yang secara de iure di bawah PTPN XII.

Dua contoh di atas, barangkali hanya sebagian yang membuktikan bahwa ternyata pasca redistribusi kelompok masyarakat berkonflik dengan kelompok masyarakat yang lain karena memperebutkan kavling tanah, atau memperebutkan kondisi tanah yang berlainan secara fisik maupun tehnis budi daya lahan. Hilangnya kesempatan dan ketidakmampuan menanggung ongkos produksi mengakibatkan pemegang hak menyerah dan akhirnya melakukan peralihan hak kepada tuan tanah pemilik modal. Pada akhirnya penguasaan lahan di eks perkebunan hanya dimiliki oleh beberapa orang yang akhirnya menjadi tuan-tuan tanah baru (newest landlord).

Hasil penelitian lapang yang dilakukan oleh tim Akatiga di dusun Keprasan Desa Gendis Kecamatan Ngrekoso Kabupaten Blitar tentang konflik HGU masyarakat dengan NV Gunung Keloed juga mengungkap kegagalan program landreform.Tanah-tanah yang berhasil diduduki sebanyak $75 \%$ disewakan. Artinya sebenarnya tujuan landreform agar petani dapat memperoleh tanah pertanian dan mengolahnya sendiri tidak tercapai. Dengan demikian terjadi tujuan tuntutan redistribusi tanah yang dimohon sebagai obyek landreform dengan hasilnya tidak sesuai dengan apa yang dikehendaki.

Secara spesifik periksa KOMPAS mengenai resesi global akibat ambruknya bursa saham di USA karena kasus Lehman Brothers 15 September 2008, 28 Oktober 2008 hal.1, KOMPAS 11 Desember 2008. hal.l. Koran TEMPO, 17 November 2008 hal.A12 -13 diprakirakan pertumbuhan ekonomi Indonesia menurut Justin Wood hanya 3,7\%, A T Prasetiantono memprakirakan 5-5.5\%. 


\section{Kemampuan Perusahaan Perkebunan Melaksanakan CSR Aspirasi Stakeholder terhadap Model ecara keseluruhan adalah sebagai berikut}

Bergulimya gagasan Corporate Social Responsibility (CSR), sesungguhnya bukan merapakan sesuatu yang benar-benar baru sebagai sebuah formula untuk mengatasi problema sosial-eknomi dan hukum pada konflik tanah-tanah perkebunan khususnya merupakan hal yang menarik untuk diperbincangkan. CSR yang pada awalnya merupakan sebuah gerakan yang terjadi di Amerika Utara dan Eropa Barat untuk melakukan perubahan unjuk kerja sosial dan lingkungan perusahaan multi nasional (TNC/MNC) yang menanamkan usahanya di negara-negara yang sedang berkembang pertengahan tahun 1990an.

Mengenai pengertian CSR, also called corporate responsibility, corporate citizenship, responsible business and corporate social opportunity) is a concept whereby organizations consider the interests of society by taking responsibility for the impact of their activities on customers, suppliers, employees. shareholders, communities and other stakeholders, as well as the environment. This obligation is seen to extend beyond the statutory obligation to comply with legislation and sees organizations voluntarily taking further steps to improve the quality of life for employees and their families as well as for the local community and society at large.The practice of CSR is subject to much debate and criticism. Proponents argue that there is a strong business case for CSR, in that corporations benefit in multiple ways by operating with a perspective broader and longer than their own immediate, short-term profits. Critics argue that CSR distracts from the fundamental economic role of businesses; others argue that it is nothing more than superficial windowdressing; still others argue that it is an attempt to preempt the role of governments as a watchdog over powerful multinational corporations. Hal demikian dilakukan untuk menghapuskan kesan mendalam seolah-olah telah terjadi penjajahan baru negara ekonomi kuat terhadap negara-negara berkembang yang kenyataannya tak terbantahkan.

Sebelum ada gagasan CSR khususnya di Indonesia pada era awal tahun 1980an telah dicanangkan pemerintah Orde Baru pola kemitraan antara perusahaan besar (perusahaan yang disebut inti) dengan kewajiban moral membina dari sisi keuangan, manajemen, 
produksi bahkan sampai pasca produksi perusahaan kecil yang biasanya berbasis industri rumah tangga dinamakan perusahaan plasma. Pola kemitraan ini hampir mirip dengan pola kemitraan (business partnership) antar dua atau lebih perusahaan untuk saling memberi/membina sehingga diharapkan pada suatu ketika perusahaan yang dibina akan dapat mandiri (self sufficient). Namun, sudah diketahui bersama bahwa dalam praktik kelemahan pada sistem pembinaan ini adalah menjaga kuntinuitas/keberlangsungan sistem pembinaan, serta dimilikinya tanggang jawab secara moral dan profesionalitas bahwa uang yang diberikan bukan merupakan hibah melainkan hanya sebatas stimulus yang harus dipertanggungjawabkan secara transparan dari segi ekonomi maupun yuridik. Namun apa yang terjadi pada sisi budaya yang bertautan dengan mentalitas manusianya sebagian besar uang yang dikucurkan untuk memberi rangsangan dipandang sebagai hibah yang akhirnya tidak dapat dipertanggungjawabkan ${ }^{6}$. Konsekuensinya, kemudian digagaslah format CSR yang menurut teori digolongkan dalam beberapa peringkat.

Berdasarkan hasil FGD, ternyata ada hal esensial yang harus dicatat khususnya dalam mengimplementasikan CSR yaitu: apakah perusahaan perkebunan yang bersangkutan fisibel atau tidak secara ekonomi dan apakah secara yuridik status tanah yang dikuasai masih fisibel untuk diusahakan secara komersial atau tidak?. Dari berbagai lokasi penelitian lapang yang dilakukan peneliti ternyata memberikan gambaran yang secara gampang diklasifikasikan menjadi:

a) Perusahaan perkebunan yang masih menguasai sekitar $50 \%$ atau kurang dari lahan menurut SKPHnya

b) Perusahaan perkebunan yang sama sekali kehilangan lahan tanah karena proses reclaiming dan tuntutan redistribusi tanah pada era 1997/1998 atau sesudahnya.

Kentalnya pengaruh variabel politik terutama pada era pemilihan kepala daerah secara langsung sebagai akibat dari diundangkannnya Undang-undang No.22 Tahun 1999

${ }^{6}$ Menurut Koentjaraningrat terdapat tiga kelemahan mentalitas bangsa Indonesia yakni: mentalitas suka mengambil jalan pintas (menerabas), tidak suka bertanggung jawab, banyak berbicara lemah bekerja keras dalam Koentjaraningrat, "Kebudayaan. Mentalitet dan Pembangunan", (Jakarta: Gramedia, 1974). 
sebagaimana diubah oleh Undang-undang No.32 Tahun 2004 tentang Pemerintahan Daerah dimana mengamanatkan sistem pemilihan langsung. Acapkali isu tanah dipakai secara salah oleh kontestan untuk memperoleh dukungan konstituennya padahal tanah tersebut telah dilekati oleh suatu hak yang secara de facto dan de iure $\operatorname{sah}^{7}$. Dengan kuataya variabel politik pada kasus sengketa pertanahan di Jawa Timur khususnya Malang menyusul masa euphoria reformasi membawa implikasi pada macetnya proses penyelesaian yang tuntas dan berkeadilan.

Berdasarkan data yang dari Perseroan Terbatas Perkebunan Negara (PTPN) XII dapat diketahui sumber dan realisasi penggunaan dana bina lingkungan antara tahun 1998 sampai dengan triwulan III Tahun 2008 yang tersaji pada tabel di bawah ini:

Tabel 2. Realisasi Penggunaan Dana Bina Lingkungan PTPN XII1998 - Triwulan III Tahun 2008

\begin{tabular}{|l|c|c|l|}
\hline No. & Tahun & Kumulatif & \multicolumn{1}{|c|}{ Realisasi BUMN Pcduli } \\
\hline 1 & 1998 & Rp. 496.800 .000 & Rp. 100.000.000,- \\
\hline 2 & 1999 & Rp.706.000.000 & Rp.600.000.000,- \\
\hline 3 & 2000 & Rp.995.092.000 & $\begin{array}{l}\text { Penyisihan BUMN Peduli } \\
\text { Awal tahun } \\
\text { Rp.326.069.368 }\end{array}$ \\
\hline 4 & 2001 & Rp.540.969.492 & $\begin{array}{l}\text { Tahun Berjalan } \\
\text { Rp.540.845.784 }\end{array}$ \\
\hline 5 & 2002 & Rp.417.501.000 & $\begin{array}{l}\text { Keterangan dana PKBL } \\
\text { Tahun 1998 - 2007 dana } \\
\text { diambilkan dari penyisihan } \\
\text { laba perusahaan }\end{array}$ \\
\hline 6 & 2003 & Rp.404.176.000 & \\
\hline 7 & 2004 & Rp.805.262.921 & \\
\hline 8 & 2005 & Rp.1028.864.700 & \\
\hline 9 & 2006 & Rp.1501249.146 & \\
\hline 10 & 2007 & Rp.2068.091.000 & \\
\hline
\end{tabular}

${ }^{7}$ Menurut pendapat Kasie Penyelesaian Sengketa Pertanahan Kab. Malang dan Pimpinan Kebun Pancursasi Kab.Malang sengketa pertanahan di Kabupaten Malang tergolong sebagai kasus yang sulit diselesikan dengan berbagai upaya karena kuatnya kepentingan masing-masing pemangku kepentingan untuk mengukuhi pendapatnya, isu tanah dijadikan ajang kepentingan politik praktis, dengan mengabaikan kepentingan sosial yanglebih luas misalnya dalam Pilkada, Pilkades (wawancara mendalam 17 dan 21 Oktober 2008). 
Sumber Data: Laporan Sumber dan realisasi Penggunaan Dana Bina

Lingkungan PTPN XII (diolah Tim PenelitiPHBXV-1)

$\mathrm{PKBL}=$ Program Kemitraan dan Bina Lingkungan

Paparan tabel di muka, memberikan gambaran bahwa sejak pelaksanaan program kemitraan dan bina lingkungan (PKBL) sebagaimana diamnatkan oleh Peraturan Menteri Negara Badan Usaha Milik Negara No.Per-05/MBU/2007 tentang Program Kemitraan Badan Usaha Milik Negara Dengan Usaha Kecil dan Program Bina Lingkungan Pasal 9 Ayat (1) sampai (6) dan Pasal 11 Ayat (1) dan (2) mewajibkan BUMN untuk menyisihkan sebagian dari laba perusahaan pada tahun yang berjalan sebesar $20 \%$ untuk diberikan kepada masyarakat yang memerlukannya. Pertanyaan pada FGD masyarakat mana yang seharusnya menerima kucuran dana PKBL, dijelaskan bahwa dana PKBL diberikan kepada masyarakat yang benar-benar memerlukan dan memenuhi persyaratan yang ditentukan oleh perusahaan yang memberikan. Tujuan esensial dari pemberian PKBL adalah memberdayakan (empowering) masyarakat jadi bukan dana yang bersifat karitas. Mengapa demikian, karena dana yang karitas bersifat tidak mendidik dan membuat ketergantungan masyarakat kepada perusahaan pemberi dana.

\section{Aspirasi dan Persepsi Stakeholder Terhadap Model CSR}

Aspirasi dan persepsi stakeholder yang dimaksudkan dalam tulisan ini adalah aspirasi pengambil kebijakan Pemerintah Kabupaten, pemegang HGU (perkebunan) di lokasi penelitian dan masyarakat sekitar perkebunan terhadap "Model" pengelolaan HGU (perkebunan) berbasis land reform dan corporate social responsibility yang telah dirumuskan dalam penelitian tahun pertama kegiatan penelitian ini, untuk selanjutnya disebut "Model".

Pihak Kantor Pertanahan Kabupaten Malang menyatakan bahwa Model CSR mestinya dijadikan sebagai salah satu model penyelesaian konflik perkebunan HGU. Menurut S, Kasie Penyelesaian Sengketa Kantor Pertanahan kab Malang, hal yang masih krusial dalam perkebunan HGU adalah masalah konflik antara perusahaan perkebunan dengan masyarakat sekitar perkebunan. Masyarakat sekitar perkebunan dengan alasan yang bermacam-macam berusaha untuk mendapatkan tanah HGU yang dikelola oleh Perkebunan baik yang dikelola oleh Perusahaan 
Swasta maupun Badan Usaha Milik Negara (PTPN XII). Terhadap perkebunan yang dilanda sengketa ini CSR tidak akan berjalan/ dilaksanakan. Oleh karena itu, sebagai jalan keluarnya adalah memilih satu di antara dua cara, yaitu tanah diberikan kepada masyarakat yang menuntut tanah (atau disebut redistribusi tanah) atau tanah tetap dikuasai oleh pemegang HGU tetapi CSR dilaksanakan sesuai dengan model CSR yang ideal yang dapat meningkatkan kesejahteraan masyarakat.

Perumusan model memerlukan berbagai pendekatan, bukan hanya dari pendekatan hukum belaka melainkan pendekatan dari perspektif ekonomi khususnya manajemen, -politik, sosial, budaya, pertanian. Pendekatan demikian yang dalam konteks hukum disebut socio-legal approach. Namun demikian, untuk penyelesaian masalah atau sengketa sebaiknya pendekatan yang digunakan adalah pendekatan hukum saja, agar ada kepastian hukumnya. Permasalahan pengelolaan HGU di lapang sangat sulit dan rumit, karena tidak ada kepastian hukumnya. Namun demikian, penyelesaian kasus tanah perkebunan HGU seyogianya dialakukan berdasarkan ketentuan hukum yang berlaku, agar terwujud kepastian hukum, sebab penyelesaian sengketa tanah perkebunan tidak bisa diselesaikan secara musyawarah, melainkan berdasarkan hukum yang berlaku.

Sementara itu, jika memang CSR yang ditetapkan sebagai pilihan jalan keluarnya atau pemecahan dari sengketa tanah HGU tersebut, maka perusahan pemegang HGU hams menjalankan CSR yang benar. Demikian sebaliknya, jika pilihan redis yang dijadikan jalan keluar penyelesaiannya, maka lakukanlah juga dengan benar, seperti misalnya, dasar haknya apa, dasar hukumnya apa. tetapi yang jelas jika redis yang dijadikan sebagai alternatif penyelesaiannya, maka jangan diberikan hak milik, sebab jika hak milik yang diberikan maka akan banyak ancaman yang datang pada tanah $\mathrm{HGU}$, seperti misalnya tanah akan ditanami tanaman yang menyimpang dari peruntukannya atau sesuka hatinya, sehingga tanaman yang sesuai dengan tanah HGU tidak dapat dipertahankan.

Model yang ditawarkan oleh Tim Peneliti PHB diolah dari hasil wawancara dengan staf Kantor Pertanahan, S, Direktur PTPN XII UBS Malang di lokasi penelitian dan Hasil FGD di PTPN XII17 Oktober 2008 dan Brawijaya Guest House tanggal 21 Oktober 2008 masih terlalu umum, seperti misalnya masih belum memberikan penjelasan tentang mekanisme pelaksanaan 
model CSR yang ditawarkan. Sebaiknya, untuk penyusunan model diperhatikan pula pengelclaan HGU yang berorientasi pada produktifitas, sehingga Model tersebut juga memasukkan pendekatan ekonomi, pendekatan pertanian dan pendekatan kesejahteraan masyarakat.

Aspirasi dan tanggapan PTPN XII digambarkan sebagaimana narasi berikut: PTPN XII pada dasarnya sudah melakukan CSR walaupun dengan nama yang berbeda. Sebelum reformasi, nama CSR yang digunakan oleh perusahaan adalah Corporate Responsibility (CR). Sejak tahun 2000 CR menjadi Program Kemitraan dan Bina Lingkungaii disingkat PKBL. Besarnya PKBL tergantung pada laba. Rincian besarnya PKBL dapat dilihat pada bagian lampiran laporan ini. Pada tahun 2007 PKBL yang diberikan yaitu $2 \%$ untuk Kemitraan dan 3\% untuk program Bina Lingkungan.

Penentuan besarnya PKBL di dalam tubuh PTPN XII pada dasarnya adalah hasil dari proses perdebatan (tawarmenawar/bargaining) pada saat Rapat Umum Pemegang Saham (RUPS). Hal demikian ada panduannya, namun kenyataannya tergantung pada Direksi dan Dewan Komisaris.

PTPN XII membawahi 14 perkebunan di seluruh Jawa Timur, di antaranya adalah Perkebunan Pancursari, Kabupaten Malang, Perkebunan Kertosono, Lumajang; Perkebunan Sirahkencong, Blitar, Perkebunan di Kediri, perkebunan Kalibakar di Kabupaten Malang, perkebunan Bangelan Kabupaten Malang, perkebunan Wonokitri, di Kabupaten Malang, dan perkebunan Malangsari di Banyuwangi.

Dalam kaitannya dengan CSR atau PKBL, PTPN XII membuat berbagai program, mulai dari program bantuan pengadaan dan pemeliharaan ternak dengan sistem bergulir, sampai pada pembangunan jalan, masjid dan program beasiswa. PTPN XII hingga saat ini tetap menjalankan program PKBL dengan melibatkan semua perkebunan yang ada di wilayahnya. Sebagai gambaran kongkrit misalnya, untuk program pembuatan jalan, jika masyarakat sekitar perkebunan merencanakan pembuatan jalan dan mengusulkan lewat PKBL maka usulan tersebut setelah di bahas di internal PTPN XII, maka usulan tersebut jika dinilai layak maka akan diwujudkan.

Persepsi PTPN XII terhadap model dinyatakan bahwa model masih belum konkrit sebagaimana Model PKBL yang dimiliki 
oleh PTPN XII. Oleh karena itu PKBL dapat dijadikan sebagai referensi untuk perumusan model.

Aspirasi dan tanggapan pengusaha pemegang perkebunan swasta digambarkan sebagai di bawah ini.

Aspirasi dari pengusaha pemegang perkebunan swasta pada dasarnya hampir sama dengan PTPN XII yang menyatakan bahwa CSR sudah lama dilaksanakan oleh perkebunan-perkebunan swasta. perkebunan Gangsar di Blitar, sudah memberikan fasilitas kepada para pekerja perkebunan, yang berupa masjid, jalan desa, penanaman tanaman di sela-sela lahan HGU, dan sebagainya. Namun demikian, CSR yang dilaksanakan oleh perkebunan Gambar sebagian porak poranda setelah era transisi, dimana karyawan perusahaan perkebunan yang diprovokasi oleh para provokator menuntut hak atas tanah HGU. Dimulai pertama pada tanggal 2 Juli 1998, karyawan mengadakan demonstrasi di kebun dengan memblokir kebun dan menyegel pintu pabrik, mereka mendiskreditkan pemegang HGU beserta karyawan yang masih loyal dengan menyatakan bahwa yang ada di kebun itu adalah antek kolonial, namun disayangkan perbuatan anarkhis itu terjadi.

Pada saat ini perkebunan Gangsar masih berusaha untuk bangkit kembali dengan menata kembali model pengelolaannya dan memastikan kembali kepemilikan HGU-nya. Sambil menunggu kepastian hukum akan kepemilikan HGU-nya yang sedang dirundung masalah, perkebunan masih dapat mengelola lahan perkebunan yang secara de facto masih di kelolanya.

Pengelolaan lahan perkebunan Gangsar yang sempat kandas di waktu reformasi, kini mulai berjalan kembali, walaupun jenis tanaman yang di tanamnya itu tidak sesuai dengan jenis tanaman yang dicantumkan pada saat penerimaan HGU pertama. Hal ini dimaksudkan untuk menutup kekurangan-kekurangan modal yang dibutuhkan segera . dimana dalam jangka waktu pendek perkebunan harus mendapatkan pemasukan (dana) agar perusahaan perkebunan tetap bertahan eksis.

Persepsi perusahaan perkebunan terhadap model dinyatakan bahwa model masih perlu dikembangkan lagi lebih detil. Misalnya menyangkut kerarigkanya, ruang lingkupnya, mekanisme kerjanya dan sebagainya. Hal yang tidak kalah penting juga model harus dapat dialaksanakan, oleh perusahaan perkebunan kepada masyarakat sekitar perkebunan. Masyarakat sekitar perkebunan ini juga memerlukan kriteria yang jelas, agar tidak menimbulkan permasalahan di kemudian hari, seperti pertanyaan : siapa yang di 
CSR ? Bagaimana bila ia meninggal dunia, apakah diganti pada ahli warisnya ? Bagaimana jika ia ternyata sudah tidak di tempat, apakah mereka masih mendapat bantuan? Apakah masyarakat yang mendapat bantuan dari CSR hanya yang ada di dalam lokasi kebun atau sampai pada mereka yang tinggal di luar kebun? Melihat dari berbagai persoalan yang dapat muncul dari CSR itu sendiri, nampaknya perlu rincian lebih lanjut tentang model CSR.

Aspirasi dan tanggapan Pengusaha manajemen perkebunan swasta digambarkan seperti berikut.

Aspirasi masyarakat sekitar perkebunan mengharap bantuan dari perusahaan perkebunan itu berjalan terns. Masyarakat perkebunan Ngadilangkung Kabupaten Kediri misalnya, sangat menyayangkan gagalnya perusahaan perkebunan mengelola perkebunannya. Pada saat perkebunan masih aktif atau produkrif, perusahaan perkebunan Ngancar, telah memberikan beberapa bantuan terhadap masyarakat sekitar perkebunan, baik itu yang menjadi pekerja perkebunan maupun yang bukan. Bantuan nyata yang diberikan adalah pembangunan mushola dan balai desa. Saat ini setelah perkebunan Ngadilangkung ini bangkrut (pailit) tentu tidak bisa berbuat apapun pada masyarakat sekitar. Namun demikian, masyarakat masih bisa juga menikmati beberapa lahan kosong untuk dipakai sebagai lahan olah raga seperti lapangan sepakbola yang dipakai oleh masyarakat khususnya para pemuda desa di sekitar perkebunan.

Aspirasi masyarakat sekitar perkebunan Wonokitri dinyatakan bahwa mereka telah mendapatkan bantuan dari perkebunan Wonokitri Kecamatan Konten. Bantuan berupa peliharaan ternak, seperti sapi dan kambing, pinjaman modal dan perbaikan sarana jalan. Masyarakat sekitar perkebunan Wonokitri tidak sampai menuntut lebih kepada perusahaan perkebunan. Masyarakat sangat loyal terhadap perusahaan perkebunan, karena merasa bahwa perusahaan perkebunan telah memberikan sesuatu yang cukup untuk dirinya.

Demikian pula, masyarakat sekitar perkebunan Gangsar di Blitar yang saat ini loyal pada perusahaan perkebunan. Masyarakat adalah para karyawan perusahaan perkebunan Gangsar yang turut serta berjuang agar perusahaan Gangsar itu dapat bangkit kembali. Masyarakat tidak mau menuntut sesuatu di luar kelayakan seperti sebagai karyawan perkebunan. Masyarakat hanya memerlukan penghasilan yang tetap dengan bekerja di perusahaan perkebunan dan perusahaan perkebunan 
memperhatikan kehidupan sehari-harinya dengan memberikan fasilitas yang dapat meningkatkan penghasilannya. Masyarakat diberikan izin untuk menanam tanaman di sela-sela lahan HGU, yang hasilnya dipakai sendiri untuk mendukung keperluan hidup serhari-hari.

Data menunjukkan bahwa keberadaan CSR sangat dibutuhkan, oleh baik pemegang HGU maupun masyarakat sekitar perusahaan perkebunanan HGU. Sebagaimana dituangkan pada tabel berikut:

TABEL 3 Persepsi Responden Terhadap Lembaga CSR di Tiga Lokasi Penelitian

\begin{tabular}{|l|l|c|c|}
\hline No & \multicolumn{1}{|c|}{ Persepsi Responden } & Frekuensi & $\%$ \\
\hline 1 & $\begin{array}{l}\text { CSR merupakan salah satu wujud } \\
\text { kepedulian sosial perusahaan perkebunan } \\
\text { dengan masyarkat sekitar kebun. }\end{array}$ & 7 & 25 \\
\hline 2 & $\begin{array}{l}\text { CSR mendekatkan hubungan perusahaan } \\
\text { dengan warga masyarakat sekitar kebun }\end{array}$ & 5 & 17,86 \\
\hline 3 & $\begin{array}{l}\text { CSR memberikan kesempatan untuk } \\
\text { menikmati hasil tanah perkebunan }\end{array}$ & 7 & 25 \\
\hline 4 & $\begin{array}{l}\text { CSR memberikan kesempatan warga } \\
\text { mengembangkan potensi ekonomi dengan } \\
\text { diikungan perusahaan perkebunan }\end{array}$ & 9 & 32 \\
\hline
\end{tabular}

Sumber: Data Primer 2008 (diolah) $\mathrm{N}=28$

Perusahaan perkebunan HGU juga menyadari bahwa CSR itu juga penting sebagai sarana untuk mempersatukan pengusaha perkebunan dengan masyarakat sekitar perkebunan. Pemikiran pengusaha perkebunan yang menguasai tanah HGU perlu mendapat apresiasi, karena pada dasarnya masyarakat telah dapat menikmati tanah garæpan yang nota bene adalah milik negara. Rakyat adalah bagian dari konsep negara, oleh karena itu, dalam pengelolaan lahan HGU, pengusaha perkebunan HGU tidak boleh melupakan rakyat dengan kata lain hams memperhatikan rakyat (masyarakat) setidak-tidaknya masyarakat di sekitar perkebunan yang langsung berdekatan (berhubungan) dengan lokasi lahan HGU.

Tanah perkebunan yang tidak ada landasan haknya dikuasai negara dan dikelola untuk kepentingan negara dan kemakmuran rakyat. Oleh negara yang diwakili oleh pemerintah diberikan kepada pengusaha melalui perusahaan swasta dan BUMN. 


\section{B. Beberapa Alternatif Model Pengelolaan HGU Berbasis CSR}

FGD di Guest House Brawijaya, tanggal 21 Oktober 2008 menghasilkan pokok-pokok rumusan sebagai berikut:

a. Sudut Pandang dari Pihak Perkebunan Swasta

1. Menurut Kepala Perkebunan Swasta Kabupaten Blitar RW, perkebunan swasta setelah tahun 1998 mengalami kemunduran yang signifikan akibat adanya reformasi politik. Berbeda dengan perkebunan BUMN yang hanya sebentar mengalami goncangan dan cepat pulih, perkebunan swasta hams betul-betul berupaya sendiri supayatetap "hidup". Hal ini diperumit lagi dengan sulitnya mencari pinjaman dana dari lembaga keuangan (bank) karena ketidakpercayaan atau dianggap kelayakan fmansialnya tidak bagus. Pada akhirnya perusahaan swasta milik RW dapat berjalan normal kembali disuport oleh penanaman tebu yang cepat memberikan kontribusi keunrungan.

2. Perusahaan Perkebunan swasta mempunyai sistem sendiri yang dikenal sebagai Sistem Reklasifikasi dalam rangka pemenuhan CSR. Pengkelasannya sebagai berikut:

- Perkebunan Kelas I: wajib melaksanakan CSR Perkebunan;

- Kelas II: Wajib melaksanakan CSR Perkebunan;

- Kelas III: tidak wajib melaksanakan CSR;

- Perkebunan Kelas IV dan V: perusahaan yang hampir bangkrut (bandingkan Agus Pakpahan ${ }^{8}$, 2000: 26-27).

${ }^{8}$ Dalam kajian Agus Pakpahan mengemukakan untuk menata perkebunan bagi kesejahteraan masyarakat luas digulirkan konsep Membangun Perkebunan Abad 2I: Membalik Arus dan Gelombang Sejarah dengan visi "mewujudkan perkebunan efisien, produktif dan berdaya saing tinggi untuk sebesar-besar kemakmuran rakyat secara berkeadilan dan berkelanjutan melalui pengelolaan sumber daya secara optimal dan berkesinambungan". Operasionalisasi visi tersebut dijabarkan melalui program:
a. Petani harus menjadi pelaku utama dalam usaha on-farm dengan meningkatkan skala usahanya/kapabilitasnya;
b. Memberikan insentif yang tinggi bagi para pengusaha di bidang perkebunan yang selalu memperbaiki teknologi maupun manajemen yang digunakan;
c. Memberikan insentif pada dunki ur.aha di bidang perkebunan yang membangun ilmu,teknologi, peningkatan kualitas SDM bidang perkebunan;
d. Membangun kelembagaan keuangan secara khusus untuk membiayai usaha perkebunan;
e. Membangun lembaga pemasaran sebagai media berkembangnya pasar komoditi perkebunan;
f. Melengkapi peraturan perundang-undangan yang mampu mendorong investasi bidang perkebunan; 
3. Mengingat sistem reklasifikasi tersebut, berarti hanya Perkebunan Kelas I dan II saja yang mampu dan dituntut inelaksanakan CSR. Pada prakteknya, tiap-tiap perkebunan swasta mempunyai masalah-masalah yang berbeda dan masing-msing mencari pemecahan sendiri-sendiri yang diarahkan ke CSR. Beberapa anggapan masyarakat adalah: dikatakan masyarakat sekitar sejahtera jika sudah kebagian tanah. Kebun milik RW, telah melepaskan 212 ha tanah dari 800 ha di Gangsar Blitar, namun hal demikian tidak serta merta memecahkan masalah.

4. Memirut RW, tidak jelas kategori masyarakat yang dikenai CSR karena tiap perusaliaan perkebunan dan masyarakat sekitarnya mempunyai titik tolak atau cara pandang yang berbeda-beda. Masalahnya yang perlu dibina adalah interaksi antara perusahaan dan masyarakat sekitar yaitu dengan cara pemberdayaan masyarakat sekitar, misalnya dalam radius $30 \mathrm{~km}$ bagi perkebunan swasta kelas I. Dengan demikian akan tercapai hubungan positif yang saling menguntungkan antara perkebunan swasta dengan masyarakat sekitar dalam rangka terpenuhinya CSR.

5. Besamya CSR (berapa \%) juga tidak ditentukan secara baku dalam perkebunan swasta namun berpatokan pada sistem reklasifikasi tersebut. Dana CSR umumnya diambil dari laba yang diperoleh perusahaan

\section{b. Sudut Pandang Pihak PTPNXII \\ 1. secara umum sistem manajemen perkebunan berjalan lancar seperti perkebunan Bangelan (produsen kopi robusta), Wonokitri}

g. Membangun saran dan prasarana;

h. Meningkatkan rasa cinta dan kebanggaan masyarakat terhadap produk perkebunan dalam negeri;

i. Secara konsisten menerapkan pohtik industrialisasi yang berbasis pada pengembangan agroindustri dan agribisnis.

Kritik peneliti, pengembangan industri perkebunan harus dijaga melalui perangkat hukum disertai dengan penegakanhukum yang konsisten agar tidak mengambil tanah-tanah rakyat tanpa ganti-rugi atau dengan ganti igi yang jauh di bawah harga pasar. Disamping itu harus dicegah pengembangan komoditi perkebunan secara gegabah tanpa/ tidak mematuhi ketentuan UU No.26 tahun 2007 tentang Penataan Ruang khususnya RTRW, penatagunaan tanah (PP No. 16 Tahun 2004), UU No.41 Tahun 1999 tentang Kehutanan. Studi beberapa LSM terhadap pengembangan industri perkebunan baik di Jawa/di luar Jawa mengakibatkan ieforestasi hutan, degradasi lingkungan yang dahsyat dalam Rimbo Gunawan dkk., "Industrialisasi Mutanan dan Dampanya Terhadap Masyarakat Adat, Kasus Kalimantan Timur", Cetakan Pertama, (Bandung: Yayasan Akatiga,1998,. hal. 19-73. 
(perkebunan teh dan kapuk randu), dan perkebunan-perkebunan lain di Kabupaten Malang, Jember dan Lumajang. Sementara itu, yang masih merupakan kasus adalah Perkebunan Pancursari dan Kalibakar.

2. PTPN telah melaksanakan sistem CSR dengan baik dan hal itu merupakan kewajiban, bukan filantropi ${ }^{9}$. Hal ini didasarkan pada Keputusan Menteri BUMN No KEP-236/MBU/2003. Dana CSR diambil dari persentase laba, dengan demikian besarnya nilai CSR tiap tahun bisa berbeda-beda tergantung besarnya keuntungan. Rincian alokasi dana untuk CSR adalah sebagai berikut:

- $3 \%$ penyisihan laba digunakan untuk Bina Lingkungan (Hibah -> dana tidak kembali);

- $2,5 \%$ dari penyisihan laba digunakan untuk program kemitraaan (berupa pinjaman lunak bagi masyarakat sekitar yang membutuhkan. Jika pinjaman telah diangsur, maka dana tersebut digulirkan lagi sehingga dana CSR untuk program kemitraan bersifat akumulatif yaitu tiap tahun semakin banyak penerima dana CSR).

3. Sasaran masyarakat yang akan didanai CSR (berdasarkan pengelompokan oleh pihak PTPN XII) sudah jelas, meliputi:

- karyawan lepas/paruh waktu;

- masyarakat luar perkebunan dalam radius $30 \mathrm{~km}$ terutama pengusaha-pengusaha kecil seperti pengrajin, pedagang, atau pemelihara ternak.

${ }^{9}$ Bandingkan dengan model pengembangan HGU yang akan berakhir tanahnya diduduki rakyat dilakukan pendekatan:

1 Pendekatan berdasarkan masa berakhirnya HGU Pola I 100\% koperasi HGU-2020 mengelola tahap pembaruan $75-85$ th, pola II $65 \%$ saham koperasi yang mengelola tahap perpanjangan 50-60 th, pola III saham $20 \%$ koperasi mengelola HGU baru 25 35 th;

2 Pendekatan berdasarkan klas kebun 1,11 mengikuti pola III, kebun klas III mengikuti pola II $65 \%$ saham koperasi, klas IV \& V mengikuti pola I $100 \%$ koperasi

3 Pendekatan pemanfaatan lahan $>80 \%$ mengikuti pola III, pemanfaatan $50-79 \%$ mengikuti pola II, pemnafaatan, $50 \%$ pola I

4 Optimalisasi pendayagunaan HGU perorangan lahan $<25$ ha dengan pembinaan

5 Pembentukan sekretariat bersama menurut Kep Ka BPN No.211-VIII-20O0 28 Juni 2000, monitoring

6 Pembentukan tim investasi menurut Kep Dirjen Bun No.349/Vll-DIR/2000 8 Juni 2000

7 Hearing Dirut PTPN dengan Komisi III DPR

8 Lokakarya Nasional Perkebunan: Membangun Perkebunan Abad 21. (Agus Pakpahan,2000: 26-30). 
Pada kenyataannya, masib banyak masyarakat penerima dana CSR untuk program kemitraan yang tidak menggunakan dana seperti diajukan dalam proposal ke PTPN XII, misalnya disalahgunakan untuk kepentingan konsumtif membeli kendaraan bermotor yang menghambat sistem pengguliran dana.

Berdasarkan masukan di muka, dapat disimpulkan bahwa model pengelolaan HGU bagi PTPN dan perkebunan swasta tidak dapat disamakan karena pengelolaan, sistem manajemen, resiko masingmasing perkebunan berbeda, yang bisa dikatakan sama adalah teknik pengolahan hasil perkebunan.

Berdasarkan hasil wawancara mendalam dan diskusi terbatas dalam Forum FGD terhadap model yang dihasilkan pada draf laporan penelitian pertama dan di revisi pada saat menjelang FGD maka dapatlah dirumuskan tiga model yang mampu tim peneliti tawarkan, sebagai berikut:

1. Pembentukan koperasi di tengah pergaulan masyarakat sekitar perkebunan, yang tidak terkait secara struktural dengan struktur organisasi perusahaan;

2. Pembentukan unit atau bagian khusus yang berfungsi, bertugas dan bertanggung jawab melaksanakan CSR.

Dengan demikian, kedua model tersebut di atas harus memuat prinsip-prinsip model sebagai berikut:

1. Model Pengelolaan HGU berbasis land reform dan CSR berbeda antarA BUMN (PTPN) dengan perusahaan perkebunan swasta;

2. CSR hanya dapat dilaksanakan oleh perusahaan perkebunan yang tidak bersengketa dan secara de facto masih mengelola tanah HGU;

3. Redistribusi Tanah bukan merapakan suatu solusi dari pengelolaan HGU yang diminta oleh rakyat;

4. Pengelolaan Tanah HGU berbasis Land reform dan CSR bukan berarti tanah HGU itu diredis, tetapi terhadap lahan HGU yang berasal dari redis tanah HGU, pemegang HGU seyogianya masih tetap memperhatikan keberadaannya melalui program CSR;

5. Model harus bermanfaat terhadap masyarakat sekitarnya. Pertanyaannya: seberapa besar manfaat (kesejahteraan) yang harus diberikan oleh perusahaan kepada masyarakat sekitarnya? Berapa perbandingan jika dipresentasikan antara manfaat yang harus diambil oleh perusahaan (selaku pemilik) dan manfaat yang harus diterima oleh masyarakat sekitar (selaku bukan pemilik/warga sekitar perusahaan/atau mungkin para pekerja 
prusahaaan atau buruhnya sendiri)? Kemudian, apa dasarnya pembagian ini, belas kasih, atau dinikmati bersama, pendidikan atau apa? Pada bidang perusahaan perkebunan landasan filosofisnya adalah mengenai perolehan, kesempatan mendapatkan tanah garapan sendiri di samping bekerja sebagai buruh pabrik.

6. Landasan Pelaksanan CSR:

Landasan pelaksanaan CSR sebagai suatu pijakan penting dimiliki oleh Perusahaan, hal ini selain berfungsi sebagai landasan atau pijakan juga sebagai paradigma yang dianut oleh suatu perusahaan dalam menjalankan program CSR. Landasan ini dapat berwujud:

a) Undang-undang, dengan pemikiran pelaksanaan CSR karena diperintahkan dalam Undang-undang, maka sudah tentu itu merupakan suatu kewajiban bagi suatu perusahaan untuk menjalankannya. Dengan demikian, tanpa melihat kondisi atau kemampuan suatu perusahaan, maka semua perusahaan wajib memenuhi ketentuan undang-undang, yaitu menjalankan CSR. Tinggal berapa besar dan bagaimana bentuk CSR yang harus ia keluarkan. Termasuk bagaimana cara menghitung besarnya CSR agar benar-benar suatu perusaahaan telah memenuhi kewajiban sesuai peraturan perundangan.

b) Filantropi, yaitu belas kasih perusahaan pada masyarakat sekitarnya. Perusahaan tidak memandang CSR semata sebagai suatu kewajiban undang-undang, tetapi lebih pada belas kasih kepada masyarakat sekitarnya yang perlu dibantu.

c) Edukasi, yaitu perusahaan memberikan perhatian kepada masyarakat yang bersifat mendidik agar masyarakat makin maju. Ungkapan yang tepat dalam bentuk edukasi ini adalah: Perusahaan tidak memberi ikan tetapi kail.

d) Empowering (pemberdayaan), yaitu pemberdayaan masyarakat sekitar perkebunan (Self Sufficient) agar masyarakat makin maju, makmur dan mandiri, tidak mau menggantungkan harapan kepada pihak lain, sehingga masyarakat sekitar tidak hanya menerima bantuan yang konsumtif saja, melainkan menerima sarana dan prasana, serta keterampilan/ keahlian yang dapat menunjang ke arah yang lebih baik dalam meningkatkan taraf hidupnya. 
7. Kepedulian Sosial:

Kepedulian sosial sebagai suatu konsep merupakan kepedualian suatu perusahaan pada masyarakat sekitarnya, yang berupa melaksanakan suatu upaya/kegiatan yang bertujuan masyarakat dapat hidup layak terpenuhi kebutuhannya dan hidup berdampingan dengan perusahaan secara rukun dan damai.

Subyek kepedulian sosial adalah perusahaan perkebunan dan sasarannya adalah masyarakat sekitar perkebunan.

Permasalahannya adalah siapakah orang-orang yang tergolong dalam kelompok masyarakat sekitar perkebunan yang menjadi sasaran kepedulian sosial tersebut ? Sasaran kepedulian sosial adalah buruh/pekerja perkebunan dan anggota masyarakat yang tinggal di sekitar perkebunan.

Masalahnya adalah berapa jarak anggota masyarakat yang tinggal di sekitar perkebunan dengan lokasi perkebunan itu sendiri ?

Relita, untuk masyarakat sekitar perkebunan yang tertentu dapat dibedakan karena ada masyarakat sekitar perkebunan yang memang bermukim di sekitar perkebunan, karena disediakan tempat oleh perusahaan atau relokasi, atau karena secara nyata merupakan bagian dari kawasan perkebunan.

Namun, di lain pihak terdapat komunitas atau kelompok masyarakat yang juga dekat dengan lokasi perkebunan karena masyarakat "merasa" dekat (diukur dari sosial-budaya atau teknis). Oleh karena itu untuk menentukan kelompok masyarakat yang terakhir ini perlu ditentukan, siapa yang akan menentukan ? Perusahaan atau masyarakat ? Penentuan ini berfungsi sebagai "recognition/pengakuan" sehingga pengakuan terhadap siapa yang dimaksud masyarakat sekitar jelas dan menghindari tuntutan (dari masyarakat yang mengaku dekat dengan perusahaan). Hal ini penting ditentukan jika dikaitkan dengan pelaksanaan CSR sebagai suatu kewajiban UU, sebab dengan kewajiban tersebut maka di pihak lain muncul hak masyarakat (tuntutan masyarakat kepada perusahaan agar memenuhi CSR).

8. Parameter/tolok-ukur CSR :

Acuan yang digunakan adalah peraturan perundang-undangan, sehingga saat ini CSR masih diatur secara umum dalam UU Penanaman Modal, tetapi belum ada peraturan operasionalnya, kecuali perkebunan negara diberlakukan Peraturan Menteri Negara Badan Usaha Milik Negara No.Per-05/MBU/2007 tentang Program Kemitraan Badan Usaha Milik Negara Dengan Usaha Kecil dan Program Bina Lingkungan. 
9. Bentuk-bentuk CSR:

a. Agro bisnis:

b. Pendidikan;

c. Kesehatan;

d. Pendayagunaan usaha mikro kecil menengah;

e. Infrastruktur:

f. Pelestarian alam dan budaya;

g. Penguatan kapasitas kemasyarakatan \& pemerintahan.

10. Peringkat Pelaksanaan CSR

Perlu juga diterapkan pelabelan terhadap perusahaan yang menjalankan CSR dengan menggunakan warna, yaitu: Hijau: CSR sebagai strategi inti \& jantung bisnis Biru: CSR tidak hanya kewajiban tetapi kemutlakan (modal sosial) Merah: CSR sebagai komponen biaya yang mengurangi keuntungan Hitam: kegiatan degeneratif, mengutamakan bisnis tidak peduli aspek lingkungan \& sosial.

\section{Kesimpulan Dan Saran}

\section{A. Kesimpulan}

Dari uraian pembahasan pada makalah ini untuk menemukan model alternatif pengelolaan perkebunan dari sisi hukum, dapat disimpulkan:

1. Program landreform khususnya redistribusi tanah perkebunan bukan merupakan sebuah solusi untuk penyelesaian konflik tanah HGU perkebunan karena menimbulkan problema baru yakni konflik horizontal (antar warga masyarakat penerima redistribusi). Tidak menutup kemunkinan konflik vertikal antara masyarakat dengan pemerintah daerah dan perusahaan perkebunan tetap laten dan massif. Demikian pula program Corporate Social Responsibility (CSR) tidak dapat dilaksanakan tanpa mempertimbangkan kondisi faktual masing-masing subyek pemegang HGU, karena ada yang sudah tidak memiliki lahan. Demikian pula ada yang luas lahan HGU sudah tidak/ kurang memadai baik secara ekonomis maupun tehnis untuk melaksanakan program CSR

2. Setidaknya dapat diajukan tiga model CSR yang dapat diaplikasikan secara kondisional yakni CSR untuk perusahaan perkebunan swasta dan CSR untuk perseroan terbatas perkebunan 
negara (PTPN). Pelaksanaan CSR akan terlaksana dengan hasil yang diharapkan apabila para pemangku kepentingan benar-benar menyadari hak dan kewajiban serta secara moral memenuhi apa yang telah disepakati bersama.

3. Azas yang terkandung di dalam program CSR adalah: pemberdayaan (empowering), kemandirian (self-sufficient), transparansi, keadilan (justice), kepedulian sosial (social careness), tanggung jawab sosial (social responsibility)

\section{B. Saran-saran}

Mengacu pada simpulan di muka, maka sebagai wujud kontribusi penelitian ini, diajukan beberapa rekomendasi yakni:

1. Intervensi negara melalui produk hukum dan ekonomi untuk melindungi perusahaan perkebunan nasional dari pengambilalihan oleh perusahaan trans nasional yang kapitalistik;

2. Diperlukan penelitian lapang lebih lanjut untuk mengetahui lebih lanjut penerapan model yang ditawarkan oleh tim peneliti pada masing masing perusahaan perkebunan pemegang HGU. Tujuannya agar ditemukan kelemahan/kekurangan model tersebut dapat semakin disempurnakan;

3. Diperlukan adanya diskusi secara lebih mendalam untuk mengkaji efektifitas pelaksanaan program CSR pada masing masing perusahaan perkebunan pemegang HGU maupun warga masyarakat penerima dana stimulus dalam program CSR;

4. Diperlukan adanya tindak lanjut kerjasama secara kelembagaan antara perguruan tinggi dengan lembaga-lembaga yang terkait dengan upaya penggalangan upaya pengenalan produk unggulan pada masing-masing pemerintah daerah, khusus yang wilayahnya terdapat produk unggulan di bidang komoditi perkebunan.

5. Pembudidayaan produtk-produk unggulan sangat penting tidak saja dalam rangka peningkatan ekspor produk pertanian tetapi juga dalam rangka usaha menumbuhkembangkan pendidikan untuk mencintai produk pertanian dalam negeri dalam mewujudkan ketahanan pangan nasional. 


\section{Daftar Pustaka}

Araf Al, dan Awan Puryadi. Perebutan Kuasa Tanah, Cetakan Pertama, Yogyakarta: Lappera Pustaka Utama, 2002.

Bachriadi, Dianto, dkk. Perubahan Politik, Sengketa, dan Agenda Pembaharuan Agraria di Indonesia, Reforma Agraria, KPA Jakarta: Lembaga Penerbit FE Universitas Indonesia, 1997.

Banakar, Reza, dan Max Travers (Eds). Theory and Method in Socio-Legal Research, Onati International Series in Law and Society, Cetakan Pertama, Hart Publishing, 2005.

Chatamarrasjid, Ais. Menyingkap Tabir (Piercing The Corporate Veic), Kapita Selekta Hukum Perusahaan, Bandung: PT. Aditya Bakti, 2000.

Chrisantini, Pinky. Berawal Pari Tanah, Melihat Ke Dalam Aksi Pendudukan Tanah, Cetakan Pertama, Bandung: Yayasan Akatiga, Bandung, 2007.

Cotterrell, Roger. "Why Must Legal Ideas Be Interpreted Sociologically?", Journal of Law and Society Vol. 25 No.2, Juni 1998, Blackwell Publisher: 171-192.

Dewi, Amelia Sri Kusuma. Toyib Sugianto dan Imam Koeswahyono, Permohonan Hak Milik Atas Tanah Bekas Hak Guna Usaha Asal Hak Erfyacht PT. Perkebunan Sumbersari Petuns di Kecamatan Ngancar Kabuyaten Kediri, Skripsi Tidak Diterbitkan, Fakultas Hukum Unibraw Malang, 2004.

Franz von Benda Beckmann (Eds.). Changing Properties of Property, Berghan Rnok, Oxford, New York, 2006.

Gunawan, Rimbo, dkk.Industrialisasi Kehutanan dan Dampaknva Terhadap Masyarakat Adat, Kasus Kalimantan Timur, Cetakan Pertama, Bandung: Yayasan Akatiga, 1998.

Hardjosoedarmo, Soedigdo. Masalah Tanah di Indonesia: Suatu Studi Pelaksanaan Landreform di Djawa dan Madura, Jakarta: Bhratara, 1970.

Irianto, Yusuf. Isu-isu Stategis Pengembangan Sumber Daya Manusia, Jakarta: Insan Cendekia Press. 2001.

Istislam, dkk. Implementasi Model Penyelesaian Kasus Tanah Perkebunan Akomodatif Pada Kasus Tanah Banongan Situbondo. Jurnal Penelitian Ilmu-ilmu, Unibraw, 2000. 
Kemp, Melody. Corporate Social Responsibility in Indonesia Quixotic Dream or Confident Expectation?. Technology, Business and Society Paper No.6, December, United Nations Research Institute for Social Development, Geneve, 2001.

KPA Bandung. Toward Agrarian Reform in Indonesia, KPA Bandung, 2001.

Koentjaraningrat. Kebudayaan, Mentalitet dan Pembangunan, Jakarta: Gramedia, 1974.

Koeswahyono Imam, dan Tunggul Anshari Setianegara., Bunga Rampai Politik dan Hukum Agraria di Indonesia, Edisi Revisi Cetakan Kedua, Universitas Malang Press, Malang

Untuk Pembelajaran Socio-Legal di Fakultas Hukum", dalam Jurnal Masalah-masalah Hukum Volume 36 No.3 Juli-September 2007, Fakultas Hukum Universitas Diponegoro, Semarang.

Nugraheni, Alfa Agustin, Toyib Sugianto dan Imam Koeswahyono, Penyelesaian Segketa Atas Tanah Bekas Hak Erfacht Perkebunan Branggah Banaran Antara PT. Perkebunan Tjengkeh Dengan Masyarakat (Studi di Perkebunan Branggah Banaran, Desa Sidorejo Kecamatan Doko Kabuyaten Blitar), Skripsi Tidak Diterbitkan, Fakultas Hukum Unibraw, Malang, 2005.

Pakpahan, Agus. "Peran dan Kontribusi Perkebunan Bagi Kehidupan Masyarakat Indonesia", Makalah Seminar Pertanahan (Perkebunan), DPRD Jawa Timur, 25 November 2000, Surabaya, Mimeo.

Perseroan Terbatas Perkebunan Negara (PTPN XII) Laporan Sumber dan Realisasi Penssunaan Dana Bina Lingkungan PTPNXII (Tidak Dipublikasikan).

Rahardjo, Satjipto. Negara Hukum Yang Membahagiakan Rakyatnya, Cetakan Pertama, Yogyakärta: Genta Press, 2008.

Sumardjono, Maria SW. Tinjauan Kasus Beberapa Masalah Tanah, Cetakan Pertama, Yogyakarta: Jurusan Hukum Agraria Fakultas Hukum UGM, 1982.

Suhariningsih, Studi Terhadap Proses Peralihan dan Penselolaan HGU Kebun di Sumberurip, Kecamatan Doko, Kabupaten Blitar, Fakultas Hukum Unibraw, Malang, 2005. 
Tinjauan Status HGU Tambak Terlantar (Studi Terhadap Tanah Garapan Penduduk di desa Tegalreio, Kecamatan Tempusari, Kabupaten Lumajans, Fakultas Hukum Unibraw, Malang, 2005.

dkk. Altematif Model Pengelolaan Hak Guna Usaha (Perkebunan) Berbasis Landreform dan Corporate Social Responsibility Menuju Reforma Asraria, Laporan Hasil Penelitian Hibah Bersaing XV-1 Surat Perjanjian Pelaksanaan Penelitian No.No.320/SP2H/PP/DP2M/III/2008, Tidak Dipublikasikan, Universitas Brawijaya, Malang, 2008.

Suhendar, Endang. Pemetaan Pola-pola Sengketa Tanah di Jawa Barat, Cetakan I, Bandung: Yayasan Akatiga, 1994.

Tamanaha, Brian Z. A General Jurisprudence of Law and Society, Cetakan Kedua, New York: Oxford University Press, 2005. -. "Socio Legal Positivism and a General Jurisprudence", Oxford Journal of Legal Studies, Vol 21 No. 1 Oxford University Press.

Untung, Hendrik Budi. Corporate Social Responsibility, Cetakan Pertama, Jakarta: Sinar Grafika, 2008.

Wijardjo, Boedhi, dan Herlambang Perdana (Editor), Reklaiming dan Kedaulatan Rakyat, Cetakan Pertama, Jakarta: Yayasan Lembaga bantuan Hukum Indonesia (YLBHI) dan RCAA Institute, 2000.

Wiradi, Gunawan. Reforma Agraria Perjalanan Yang Belum Berakhir, Cetakan Pertama, Yogyakarta: Insist Press, KPA dan Pustaka Pelajar, 2000.

Zammit, Ann. Develoyment At Risk, South Centre \& United Nations Research Institute For Social Development, Geneve, 2003.

Peraturan Perundang-undangan

Undang-undang No.5 Tahun 1960.

Undang-undang No.56/PRP/1960.

Undang-undang No.2 Tahun 1960.

Undang-undang No. 10 Tahun 2004.

Undang-undang No.32 Tahun 2004.

Undang-undang No.25 Tahun 2007. 
Undang-undang No.40 Tahun 2007.

Peraturan Pemerintah No.224 Tahun 1961.

Peraturan Pemerintah No 40 Tahun 1996.

Peraturan Pemerintah No.24 Tahun 1997.

Peraturan Pemerintah No. 16 Tahun 2004.

Peraturan Presiden No. 10 Tahun 2007. 